\title{
Diagnosis of haemophagocytic lymphohistiocytosis in a resource-limited setting
}

\author{
Shivanthan $M C^{1}$, Wijesiriwardena $B^{1}$, Jayaratne $B^{2}$, Gunasekara $D^{2}$, Biyanwila $C^{1}$, Walawwatta $A^{1}$ \\ ${ }^{1}$ National Hospital of Sri Lanka, Colombo, ${ }^{2}$ Cancer Institute, Maharagama, Sri Lanka \\ Correspondence: Dr.Mitrakrishan Chrishan Shivanthan (mcs627@gmail.com)
}

\section{Case Report}

A 24-year old male from Anuradhapura was hospitalized for a cough lasting six weeks, high fever of ten days and intermittent haemoptysis of one week. He appeared ill, febrile and dyspnoeic. Bilateral diffuse wheezes and crackles were heard on chest auscultation. Non-tender firm spleen, palpable $5 \mathrm{~cm}$ below left costal margin, was found in the abdomen. No liver or lymph node enlargement was detected.

Full blood count revealed mild anaemia ( $\mathrm{Hb} 11.4$ $\mathrm{g} / \mathrm{dL}, 3$ days later decreased to $9.7 \mathrm{~g} / \mathrm{dL}$ ), leucopenia $(0.800 \times 10 / \mathrm{L}$, neutrophils $8 \%$, lymphocytes $92 \%)$ and a platelet count of $190 \times 10^{9} / \mathrm{L}$. Peripheral blood picture showed normocytic and normochromic red cells, with marked leucopenia and neutropenia with few reactive lymphoid cells. Platelets were normal in morphology. Chest radiograph showed bilateral patchy shadows mainly in the mid and lower zones on the right side (Figure). Abdominal ultrasonography confirmed bulky splenomegaly without hepatomegaly or other abnormalities. Sputum culture was positive for MRSA. Sputum examination with Ziehl Neelsen staining demonstrated acid fast bacilli $(2+)$. Bone marrow aspirate showed increased macrophages with prominent haemophagocytosis, moderate erythroid hyperplasia with moderately suppressed granulopoietic activity with no mature granulocytic series and arrest at promyelocyte- myelocyte stage. No mature neutrophils / band forms were noted or smudge cells were seen.

Trephine biopsy of the bone marrow showed hypercellular marrow spaces composed of moderately hyperplastic erythropoiesis, thrombopoiesis of normal morphology and active granulopoiesis with moderate maturation arrest at the late precursors. Macrophage activity was increased and scattered among haemopoietic tissue. Scattered lymphocytes too were seen. No lymphoid cell infiltration was noted. The possibility of 
Table: Investigations performed following bone marrow examination

\begin{tabular}{lll}
\hline Test & Result & Reference / control \\
\hline Serum ferritin & $2040 \mathrm{ng} / \mathrm{mL}$ & $28-397 \mathrm{ng} / \mathrm{mL}$ \\
INR & 2.0 & 1.0 \\
APTT & $44 \mathrm{~s}$ & $32 \mathrm{~s}$ \\
Serum Triglycerides & $136 \mathrm{mg} / \mathrm{dL}$ & $35-150 \mathrm{mg} / \mathrm{dL}$ \\
Serum bilirubin & $1.16 \mathrm{mg} / \mathrm{dL}$ & $1.1 \mathrm{mg} / \mathrm{dL}$ \\
D-dimer & $5.96 \mathrm{mg} / \mathrm{dL}$ & $<1 \mathrm{mg} / \mathrm{dL}$ \\
\hline
\end{tabular}

Bone marrow aspirate PCR for leishmaniasis, serological studies for HIV, EBV and cytomegalovirus were negative. The patient was diagnosed to have HLH secondary to pulmonary tuberculosis complicated by MRSA pneumonia.

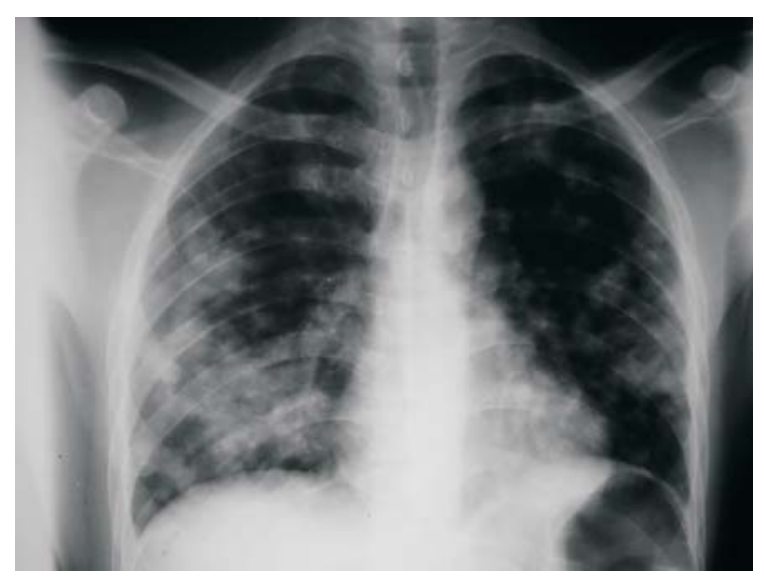

Figure: Chest radiograph of the patient showing bilateral alveolar shadows

His ESR was $70 \mathrm{~mm}$ while serum protein was 5.3 $\mathrm{g} / \mathrm{dL}$ (Albumin 2.3). Serum alkaline phosphatase, ALT, AST, serum creatinine, LDH, serum Na and K were normal. Blood cultures were negative.

\section{Discussion}

The presentation and the initial laboratory investigations of this patient were suggestive of a hematological malignancy associated with pulmonary tuberculosis secondary to immune suppression. However the bone marrow examination showed characteristic features of HLH which directed the investigators towards this diagnosis.
The Histiocyte Society diagnostic criteria for HLH (1).

\section{Main criteria}

1. Fever (more than 7 days),

2. Splenomegaly,

3. Cytopenia (2 lineages), anaemia $(\mathrm{Hb}<9.0 \mathrm{~g} / \mathrm{dL})$, thrombocytopaenia $(<100,000$ cells $)$ and neutropenia $(<1000)$,

4. Hypertriglyceridaemia $(>265 \mathrm{mg} / \mathrm{dL})$ and/or hypofibrinogenaemia $(<1.5 \mathrm{~g} / \mathrm{L}$ or $150 \mathrm{mg} / \mathrm{dL})$,

5. Haemophagocytosis (BM, spleen, lymph nodes),

\section{Additional criteria}

a. Low / absent natural killer cell activity,

b. Hyperferritinaemia ( $>500 \mu \mathrm{g} / \mathrm{L})$ and

c. Increased soluble CD25>2400 units/mL.

All five (5) main criteria or four (4) main criteria plus additional criteria of either (a) alone or a combination of (b) and (c) together are considered as diagnostic of HLH(1).

Criteria 1, 2, 5 and $b$ were found in our patent. The deranged coagulation studies with prolonged APTT, INR and elevated D-dimer level could be secondary to low fibrinogen. Leukocytopenia and the drop of haemoglobin from 11.7 to $9.7 \mathrm{~g} / \mathrm{dL}$ within 3 days, too were supportive of the diagnosis. Hyperbilirubinaemia, though characteristic in this condition, is not a diagnostic criterion. Fibrinogen 
levels, natural killer cell activity, CD25 levels were not assessed due to constraints. In a resource limited setting the described constellation of findings justifies the diagnosis of HLH.

$\mathrm{HLH}$ is rare and characterized by benign proliferation of the mature histiocyte and uncontrolled phagocytosis of the platelet, erythrocytes, lymphocytes and their hematopoietic precursors in the bone marrow causing cytopenia. Primary HLH occurs as a result of genetic inheritance. Secondary HLH occurs following infections (2), inflammatory conditions and malignancies (3). The likely causative factor in this case was pulmonary tuberculosis which is a known cause of HLH $(4,5,6,7)$. The MRSA infection was possibly secondary to neutropenia in this patient. Management of secondary HLH is directed to the treatment of the underlying cause. He was treated with vancomycin, meropenem and CAT 1 anti-TB regimen. The patient showed good clinical response to treatment; however he died later from suicide.

The authors wish to highlight the fact that the diagnosis of HLH is not easy in a setting where expensive laboratory investigations are limited due to financial and logistical constraints. It is likely that this condition has a higher incidence than documented but eludes diagnosis.

\section{References}

1. Henter JI, Horne A, Arico M, Egeler RM, Filipovich AH, Imashuku S, et al . HLH-2004: Diagnostic and therapeutic guidelines for haemophagocytic lympho histiocytosis. Pediatr Blood Cancer 2007; 48: 124-31.

2. David N. Fisman, Hemophagocytic Syndromes and Infection, Emerging Infectious Disease Vol. 6, No. 6, November-December 2000 http://www.ncbi. nlm.nih.gov /pmc/articles/PMC2640913/pdf/11076718.pdf.

3. Dhote R, Simon J, Papo T, Detournay B, Sailler L, Andre $\mathrm{MH}$, et al. Reactive haemophagocytic syndrome in adult systemic disease: Report of twenty-six cases and literature review. Arthritis Rheum 2003; 49: 633-9.

4. Browett PJ, Varcoe AR, Fraser AG, Ellis-Pegler RB. Disseminated tuberculosis complicated by the Hemophagocytic syndrome. Aust NZ J Med 1988; 18: 79-80.

5. Campo E, Condom E, Mario MJ, Cinta M, Romagosa V. Tuberculosis-associated haemophagocytic syndrome: Asystemic process. Cancer 1986; 58: 2640-5.

6. Subhash HS, Sowmya S, Sitaram U, Cherian AM. Tuberculosis-associated haemophagocytic syndrome. JPostgrad Med 2001; 47:220.

7. Goto S, Aoike I, Shibasaki Y, Morita T, Miyazaki S, Shimizu T., et al. A successfully treated case of disseminated tuberculosis-associated hemophagocytic syndrome and multiple organ dysfunction syndrome. Am JKidney Dis 2001; 38: E19. 